\title{
COMBINATION OF INNOVATIVE TECHNOLOGIES AND HISTORIC HERITAGE IN SPIRITUAL AND MORAL EDUCATION OF CADETS
}

\author{
O.V. Barskaya ${ }^{1}$ \\ ${ }^{1}$ Black Sea Higher Naval School named after P. Nakhimov of the Russian \\ Federation Ministry of Defense \\ ${ }^{1}$ 1A, Dybenko str., Sevastopol, 299028 \\ ${ }^{1}$ E-mail: olyabarska@yahoo.com
}

\begin{abstract}
The article is aimed at formulating recommendations for the use of innovative forms of cadets'spiritual and moral education for the creative connection of historical content and modern technologies in the upbringing process of military educational institutions.For that purpose the objectives, novelty, methodological framework and methods of the research are indicated.The topicality of the issue under concern is proved on the basis of a survey conducted within the naval cadet community, and the analysis of the problem study extent in modern domestic and foreign science is carried out. Based on the modern scientific researches, the definitions to the terms of spirituality, spiritual and moral education and innovative pedagogical technology were given and the functions of using informationcommunicative technologies in the process of education were figured out. The most essential part of the paper is dedicated to the methodological recommendations towards virtual excursion and competition-project technologies application in the process of spiritual and moral education of naval cadets. The project, which suggests the combination of information technologies use and archive sources and printed materials containing local history factsstudy by cadets was worked out and the topics for the similar projects realization in the future were offered.
\end{abstract}

Key words: spiritual and moral education, innovative pedagogical technology,military educational institutions, virtual excursion,competition-project.

\section{Introduction}

The reform of the Russian armed forces has led to new requirements for higher military school and future officers training to serve the Motherland. In this regard, it became necessary to change the approaches to the selection of the military education content, to the methods and means of training and upbringing in military educational institutions, to the forms of educational activities organization, to the nature of relations between teachers, commanders and cadets. Requirements to the military higher education institution graduates to be not only professionally, but also socially competent people, to possesswell-formed socially significant personality qualities, to be prepared for the changes occurring in the surrounding reality, to be guided by the values of the respectful attitude to peoplein the daily life, toha-

${ }^{1}$ Olga V. Barskaya, Senior Lecturer of Foreign Languages Department. 
ve the developed sense of duty and honor, to be disciplined and responsible [1, p. 3] began to be put forward. At the same time, the complex socio-economic and geopolitical processes that have taken place in Russia in recent decades have been accompanied by spirituality and moralitycrisis, which has covered all spheres of the society, and hence the armed forces. The definition of the term spirituality that B. Kerimbayevagivesis as follows - a property of the soul consisting in the predominance of spiritual, moral and intellectual interests over the material ones [2, p. 37]. Taking this definition into account, we note the lack of spirituality development in the military community, which is demonstrated by a survey conducted in 2018 among the cadets of higher naval educational institutions. According to the survey, $65 \%$ of informants are guided by material-consumer and socialstatusmotivesinstead of the spiritual-moral ones in choosing the profession and forming the life position. The survey results are similar to the ones by D. Miralieva, who states that spiritual development and moral self-improvement are less attractive to the young than the focus on material prosperity, good opportunities for recreation and entertainment and recognition and admiration of others [3, p. 41]. These facts make it relevant to comprehend the historical experience of solving the problems of cadets spiritual and moral education, to assess the effectiveness of the means available to the modern higher military school in this regard and to determine the potential use of a variety of techniques and methods of positive pedagogical impact on cadets.

The aim of this article is to formulate recommendations for the innovative forms of cadets spiritual and moral education use and for the creative connection of historical content and modern technologies in the upbringing process in military educational institutions.

The objectives of this study are to analyze the degree of the problem study in the modern psychological and pedagogical science; to determine the categorical apparatus of the research; to consider the ways of competition-project and virtual tour activitiesimplementing in the process of cadets spiritual and moral education.

The novelty of this study is to combine innovative pedagogical technologies of virtual tours and competition-project with specific archival, historical and local history material on the formation and development of the RussianBlack sea fleet and its naval base of Sevastopol.

\section{Review of the problem study}

In recent years, we have seen a lively scientific discussion on the research problem. Many modern domestic and foreign pedagogues and psychologists analyze the influence of various factors on the young people spiritual and moral condition and explore effective methods of educational impact on an individual. For example, the topic of museum and excursion activities is relevant for the scientific discourse of recent years. In this regard, E. Dudarenko has developed an algorithm of senior pupils spiritually-moral education pedagogical monitoring during afterhour tours of the Holy places [4]; G. Dudin provides a model for the students linguistic-cultural competence development, which is a synthesized virtual and real tour [5]; a virtual excursion as an innovative educational form is under the study by 
N. Ustyuzhanina [6]; patriotic education by means of Museum pedagogics is explored by N. Delvig, N. Selezneva [7] and a foreign teacher J. Rose [8]; other aspects of Museum pedagogy as a scientific discipline are explored in recent papers, performed by groups of auhors "The creative potential of Museum pedagogy within the modern society" [9] and the "Historical role of museums and libraries in information support of educational environment" [10]. A Taiwanese scientist Y. Yu conducted a comparative analysis of three models of moral and ethical education in military academies [11], and Russian psychologists S. Kudinov, I. Kudinova and S. Belousova used the axiological approach to identify the typology of young people value orientations, which are as follows: pragmatic-professional, socialcommunicative and individual-egoistic types of personality axiological orientation [12, p. 95]. Spiritual and moral education from a historical perspective is studied by A. Grebenkin, who traced the military and cultural traditions of officers training in pre-revolutionary Russia [1] and V. Poda, who revealed the spiritual education pedagogical concept of V. Zenkovsky [13]. The use of innovative technologies in the process of spiritually-moral education was considered by foreign teachers Hong-Mei Li and Dan Han [14]; R. Ferdig, J. Coutts, J. DiPietro, B. Lok and N. Davis discussed social networking communities and multiplayer online roleplaying games technologies [15]; Russian scientist, Professor L. Redkina revealed the potential of information and communication technologies in spiritually-moral education of servicemen [16]; N. Lapasov considered student-centered, adaptive and interactive learning education technologies [17]; S. Maksimov and Ye. Stepina studied the potential of military-historical reconstruction and staging, forming ethnic and cultural identity, patriotic consciousness and desire to know one's native land [18]; L. Lokhvytska devoted her work to the integrated game moral inclusive technology, game modeling, polylogue, besting and visualization [19]. The works by N. Vengerova [20] and O. Sapanzha [21] are devoted to the categorical apparatus in the field of Museum pedagogy and innovative pedagogical technologies. The problems of political correctness and toleranceeducation, value-forming functions of native and foreign languages learning, subject-subject interaction in crosscultural space are discussed in the articles by O. Golovko [22], A. Kagileva [23], I. Mambetova [24] and I. Starchikova [25]. Despite the problem considered in the article active presence in the modern scientific discourse, the topic of innovative technologies and historical heritage combination in cadets' spiritual and moral education, using a specific local history material was studied fragmentally.

\section{Methodological basis and methods of the research}

The methodological basis of the study is:

- system approach, as cadets spiritual and moral education has the structure of a system;

- axiological approach, as value perception of the world is the result of spiritual and moral education;

- civilizational approach, as the transformation of the society spiritual and moral state and the genesis of spiritual and moral education system are conditioned by geopolitical and socio-economic changes. 
The methods of generalization and systematization, comparative and historical-retrospective analysis of scientific literature on the research problem were used to solve theoretical problems. To analyze the level of cadets spiritual and moral development, the empirical methods of observation and questioning were applied.

\section{Research results}

A comprehensive study of any scientific problem involves its categorical apparatusdefinition. Following F. Mukhametzyanova, who studies the educational process in military schools, in this article we consider spiritual and moral education as a holistic pedagogically organized process of basic national values assimilation and adoption by cadets, the process having a hierarchical structure and complex organization [26, p. 1064].

Interpreting the definition by $\mathrm{N}$. Vengerova, we consider innovative pedagogical technology as a set of qualitatively new, original forms, techniques, methods and ways of education, which are purposefully and systematically embedded in teaching practice, substantially changing the outcome of the educational process [10, p. 103].

In today's digitalized society it is relevant to find the ways to introduce innovative forms and methods of spiritual and moral education in the military sphere, to create electronic and technical educational environment. According to L. I. Redkina, the electronic and technical environment is designed to perform a number of tasks in the educational process: the creation of a cultural potential accumulation system through the formation of the Russian army and the people as a whole intangible heritage resource base; the development of creative, social, personal and instrumental competence of students; providing mobile information to the military community and civilian society in order to form a positive image of the military service [15, p. 123].

One of the components of the electronic-technical educational environment is a virtual tour, the technology of which is discussed in the framework of Museum pedagogy, which, accordingtoK. Milovanov, hasthepotentialofcultural, informationalandupbringingpersonalityformation. Modern principles of museum environment creation combine the bases of theoretical pedagogy, philosophy of education, history, culturology and art-criticism [9, p. 446]. The specificity of this environment is the development of human individual's cultural and moral potential by means of providing the open cultural-civilizational visual-image, verbal and tactile dialogue and interaction with the objects of spiritual heritage facilitated by innovative technologies [8, p. 36].

The following recommendations can contribute to the effective preparation and conduct of a virtual tour as an innovative form of educational, cultural and educational work.

The classification of virtual tours is as follows:

- by content: review, thematic, biographical. In practice, this division is often conditional; 
- according to the creationmethod: with the help of presentation technologies; site making tools (creation of graphic maps, hyperlinks); geographic information systems (Yandex, Google); 3D modeling (creation of a separate objectmodel); use of panoramic compositions (creation of hot spots and transitions).

- The stages of a virtual tour:

- preparation -the selection of the ideological and thematic basis of the tour: development of the topic -the show and the story will be based on the topic, the choice of the topic depends on the potential demand or the purposeful creation of a virtual tours "bank"; the definition of goals and objectives - they are associated with the idea, for in the tour one provides not only the presentation of certain material, but also of clear ideological positions;

- selection of objects - the theme is revealed through pre-selected objects demonstration and enriched with certain impressions, mostly visual. The visual range should be constructed so that the topiccould be disclosedwithout a detailed story of the guide;

- making a plan, for example: Organizational moment. Introductory conversation. The story of the teacher using an electronic presentation. Quiz. Independent cadetswork. Reports of cadets on the work carried out. Summarizing;

- preparation of the text that meets the requirements of brevity, wordingclarity, factual material presence, literary language, the sequence of the text corresponding to the show, the disclosure of all sub-topics;

- conducting the tour - at the organizational moment the greeting, excursion topic, purpose, tasks and structure are announced. It is important to set up cadets to repeat and consolidate the material, if necessary, to organize their work with additional sources of information, to reveal the nature of the work to be done, to communicate the requirements for their behavior. The task of the introductory conversation is updating the cadets'knowledge on the topic. The role of the teacher in the process of conducting the main part of the virtual tour may consist in the organization of the cadets independent work in groups using electronic educational resources, instructions, guidance of their activities, advice during their viewing of the tour, as well as in setting tasks or problematic issues to activate the cadets while listening to the teacher's story. In the final conversation the information received is summarized and systematized, impressionsare expressed. At the follow on stage, quizzes, games, competitions are held, creative tasks are performed, and the information obtained in the classroom is used.

During the virtual tour it is recommended to use:

- methodical techniques of objectsdemonstration: preliminary examination allows one to identify memorable details of the object, to compare one's idea of it with its real state; panoramic display - with a virtual inspection of the area it is necessary to identify its composition center, to show the main objects in a certain sequence; visual (virtual) reconstruction of the original appearance of a partially preserved object mentally or using information-communication technologies, based on the information from the teacher'sstory; localization of events - recreation of 
historical events in a virtual area, localizing the cadets'attention using the words "right here", "at this very place", "just in this direction" and creating the effect of participation; abstraction - selection of the desired element from the whole; visual comparison and analogy;

- methodical techniquesof voice accompaniment: reference, description, characteristics - identification of distinctive properties; commenting - interpretation of phenomena and events; citation - confirmation of the thought, preserving the features of the language and specifics of a certain historical period or people, getting acquainted with the authoritative opinion; questions and answers - activation of the participants; retreat - reciting a poem, a life example to relieve fatigue and enhance attention in the future.

In General, the principles of planning and conducting a virtual tour are similar to the traditional ones, but there is a number of advantages: interactivity, accessibility of any geographical object or historical period, increasing the productivity of the educational process through digitalization, possibility of re-viewing, visibility, the effect of presence, contribution to the development of working with computer technologyskills.

The technical side of the tour presents a great difficulty when it is not about the presentation, but about 3D modeling or a panorama. In such cases, it is recommended to utilize the network ready-to-use designs. Some of them are: trips to museums and memorials of Sevastopol http://virtual-sevastopol.ru; the virtual Museum on the Ministry of defense website with the tours, panoramas, the excursion of "Varyag" cruiser - encyclopedia.mil.ru; 3D tour on the Museum of the World Ocean website of the project 641 "Foxtrot" submarine - world-ocean.ru; tours of medieval London, Russian reserves and American universities http://www.edutainme.ru/post/7-trips/; excursions to the most essential museums of the world: Louvre, Metro, Tate gallery, Hermitage https://www.gq.ru/travel/article/virtualnye-ekskursii-po-glavnym-muzeyam-mira/, the Manhattan project tour - the code name for the U.S. nuclear weapons program - k-25virtualmuseum.org.

A virtual tour can be prepared and conducted not only by a teacher, but also by a cadet during the participation in a competition-project.

Below there are the recommendations for the competition-project "The role of personalities in the history of Sevastopol" conduct, which was made up for the cadets of the Black sea higher naval school named after P. S. Nakhimov (Sevastopol). Cadets' spiritual and moral education involves project activities aimed at military history and the outstanding personalities contribution in the fleetdevelopment study. An important skill in the research work of a historical nature is to deal with documents, in particular with archival ones, to be able to extract the information from them, to systematize and generalize it. At the same time, most graduates of military educational institutions do not even have basic skills of this kind. Project creative tasks are able to combine the creative use of innovative technologies and archival documents. 
An example of such a project is "The role of personalities in the history of Sevastopol". In these recommendations, we consider the project on the example of the activities byadmiral M. Lazarev. He headed Sevastopol and the port in the period before the Crimean war (1833-1851). The buildings and structures constructed by his efforts, preserved since then, the layout and architectural style of the central part of Sevastopol are now a valuable architectural heritage. Archival documents of the Russian state archive of the Navy (St. Petersburg) and the Archive of the city of Sevastopol allow us to trace how the construction transformations of Sevastopol were conceived and implemented in practice, what difficulties this process had to facewith. Many of the buildings mentioned in the documents have not survived to the present day. However, the text information about them has been preserved.

The project is carried out in three stages. At the preparatory stage, students are explained the basic principles of archival cataloging and symbols. Then they are invited to study the archival documents published in the collections [27, 28, 29, 30] and to take notes of important information on the following topics: Sevastopol fortress; the city center (Catherine street and square, Central hill), Admiralty, Water supply system, Barracks, Count's landing stage, Naval library, Flag officers and captains assembly house, Peter and Paul Cathedral, St. Vladimir Cathedral project, The development of archeology, The use of Donetsk coal.

At the competition stage, the project leaders ask factual questions about the content of the documents, while the use of documents is allowed, but it is important to answer first. The command stage of the competition-project can be drawing from memory Lazarev era iconic objects of Sevastopol city center both preserved and lost on the contour map,. To do this, it is necessary to study the location of the following objects in the documents and the modern map of Sevastopol: Tower of winds; aqueducts in Apollo and Ushakov ravines, the Ridge of lawlessness, the Peter and Paul Cathedral, the place of the AdmiraltySt. Vladimir Cathedral establishment,Naval library (1844-1855), Catherine landing stage, Flag officers and captains assembly house, Mine (Admiralty) tower on Catherine street, the first Admiralty and a shipyard of the 1780s, Lazarev Admiralty, Lazarev barracks, Peresyp, Nikolay, Pavel, Alexander,Constantine and Mikhailbatteries. Another task of the competition is to create a sketch of the Naval library bas-relief fragment. On the basis of M. P. Lazarev's letters, cadets need to choose one plot fragment and, having studied the analogies, create a sketch of this fragment. The the sketch creator should prepare and demonstrate a presentation of his sketch and make arguments that he most accurately embodied the wishes of M. Lazarev, set out in his letters. At the end of the competition the winners are announced.

At the final stage, the leaders of the project will organize a visit to the Archive of the city of Sevastopol, where the cadets are given the opportunity to supplement the information received before. The final product of the project is a virtual tour "Lazarev places of Sevastopol" made by the cadets. 


\section{Conclusion}

Taking all the above into account, we generalize that the use of innovative pedagogical technologies in the process of spiritual and moral education in military educational institutions is an actual and discussed problem of modern science. An example of such technologies is a virtual tour and competition-project "The role of personalities in the history of Sevastopol". The regulations for such a project conduct on the example of admiral M. P. Lazarev assumes harmonious and creative connection of work with information and communication technologies, archival materials, printed editions, virtual excursion planning and carrying out. The theme of such competition-projects can be the activity of any outstanding personalities who played a significant role in the development of a region, as well as a significant geopolitical or socio-cultural phenomenon or event that left a mark on the history and present of any location. In particular, for the cadets of the Black sea Fleet of the Russian Federation it can be suggested to develop the competition-project "The Crimean war and Sevastopol", the "Four battles of the Crimean war", "The Contribution of Ja. M. Yukharin in moral and spiritual upbringing of the future Navy officers", "A. A. Khanzhonkov - the founder of media education in the Navy", "History of the Navy in the museums of Sevastopol" and many others. Participation in such projects contributes to the formation of a worthy moral ideal, the cultivation of patriotic feelings and pride in belonging to the Navy of the Russian Federation, the development of skills in working with information in documents, archival sources and improving the ability to use information and communication technologies.

\section{REFERENCES}

1. Grebenkin A.N. Voenno-kul'turnye traditsii podgotovki russkogo ofitserskogo korpusa (2-ya polovina XVII - nachalo XX v.): Avtoref. dis. doc. ped. nauk [Military-cultural traditions of Russian officer corps training (2nd half of XVII-beginning of XX century). Abstract of thesis dr. of ped. sci.]. Orel, 2017. $47 \mathrm{p}$.

2. Kerimbayeva B.T., Serickbayeva N.M. The formation of moral - spiritual qualities of future teachers in higher pedagogical education. A Young Scientist, 2017, vol. 7, no. 141, pp. 37-39. https://moluch.ru/archive/141/39701 (accessed: February 20, 2019).

3. Miralieva D.T. The impact of mass culture on the formation and development of spiritual and moral image of today's youth. East European Science Journal, 2017, no. 1, pp. 41-45. https://eesa-journal.com/en/2017/02/27/the-impact-of-mass-culture-on-theformation-and-development-of-spiritual-and-moral-image-of-todays-youth/ (accessed: February 20, 2019).

4. Dudarenko Ye.P. Pedagogicheskiy monitoring dukhovno-nravstvennogo vospitaniya starsheklassnikov posredstvom vneurochnoy ekskursionnoy deyatel"nosti [Pedagogical monitoring of senior students' spiritual and moral education by means of extracurricular excursion activity]. Pedagogika. Voprosy teorii i praktiki, 2018, vol. 3, no 11, $13-18 \mathrm{pp}$. 
5. Dudina G.O. Muzeynaya pedagogika kak sredstvo obucheniya russkomu yazyku kak inostrannomu (na primere modelirovaniya virtual'noy ekskursii po muzeyam SanktPeterburga) [Museum pedagogy as a means of teaching Russian as a foreign language (by the example of St. Petersburg museums virtual tour modeling)]. Sovremennye problemy nauki i obrazovaniya: nauchnyy elektronnyy zhurnal, 2017, vol. 6. http://science-education.ru/ru/article/view?id=27246 (accessed: February 19, 2019).

6. Ustyuzhanina N.V. Virtual"naya ekskursiya kak innovatsionnaya forma obucheniya [Virtual excursion as innovative form of education]. Nauka i perspektivy, 2017, vol. 2, 62-66 pp. https://cyberleninka.ru/article/n/virtualnaya-ekskursiya-kakinnovatsionnaya-forma-obucheniya (accessed: February 19, 2019).

7. Delvig N.A., Seleznyova N.Ye., Barskaya O.V. Virtual Museum as the Means of Future Naval Officers' Patriotic Upbringing. TSPU Bulletin, 2018, vol. 8, no. 197, pp. 115-120.https://vestnik.tspu.edu.ru/files/vestnik/PDF/articles/ Idelvig_n._a._115_120_8_197_2018.pdf (accessed February 20, 2019).

8. Rose J. Commemorative museum pedagogy. In Trofanenko B. \& Segall A. (Eds). Beyond Pedagogy. Reconsidering the Public Purpose of Museums. Rotterdam: Sense Publishers, 2014. 184 p., pp. 115-133.

9. Milovanov K.Yu., Nikitina E.Ye., Sokolova N.L., Sergeyeva M.G.The creative potential of museum pedagogy within the modern society. Revista ESPACIOS, 2017, vol. 38, no. 40, pp. 27-38. http://www.revistaespacios.com/a17v38n40/17384027.html (accessed: February 21, 2019).

10. Belenchuk L.N., Zanaev S.Z., Kondratieva G.V., Milovanov K.Yu., Nikitina E.E., Polovetsky S.D. Historical role of museums and libraries in information support of educational environment. The European Proceedings of Social \& Behavioural Sciences EpSBS, 2018, vol. XLVI, pp. 445-451. https://dx.doi.org/ 10.15405/epsbs.2018.09.02.52 EEIA-2018 (accessed: February 20, 2019).

11. Yu Y.M. Comparative study of the military academy moral education model. International Journal of Ethics Education, 2016, no. 1, pp. 25-42.

12. Kudinov S.I., Kudinov S.S., Kudinova I.B., Belousova S.S. The axiological orientation of students' personalities. Psychology in Russia: State of the Art, 2018, vol. 11, no. 1, pp. 95-105.

13. Poda V.N. Theoretical principles of spiritual and moral education defined by V. Zenkovskyi. A Young Scientist, 2016, vol. 3, no. 107, pp. 897-900. https://moluch.ru/archive/107/25620/ (accessed: February 20, 2019).

14. Hong-Mei Li, Dan Han. Innovation research of moral education based on excellence engineer training program. International Journal of Cognitive Research in Science, Engineering and Education, 2013, vol. 1, no. 2, pp. 106-113.

15. Ferdig R., Coutts J., DiPietro J., Lok B., Davis N. Innovative technologies for multicultural education needs. Multicultural Education \& Technology Journal, 2007, vol. 1, no. 1, pp. 47-63. https://www.learntechlib.org/p/101397/ (accessed: February 18, 2019).

16. Red'kina L.I. Ispol'zovanie informatsionno-kommunikatsionnykh tekhnologiy $\mathrm{v}$ protsesse dukhovno-nravstvennogo vospitaniya $\mathrm{v}$ obrazovatel'nykh uchrezhdeniyakh voennogo profilya [Use of information and communication technologies in the process of spiritual and moral education at military schools]. Vestnik SamGTU: Seriya Psikhologo-pedagogicheskie nauki, 2017, vol. 4, no 36, 121-130 pp.

17. Lapasov N.Sh.The role of innovative technologies in education. A Young Scientist, 2017, no.15, pp. 598-600. https://moluch.ru/archive/149/42206/ (accessed: February 18, 2019). 
18. Maksimov S.N., Stepina Ye.G. Voenno-istoricheskaya rekonstruktsiya kak sotsiokul"turnyy fenomen i sredstvo patrioticheskogo vospitaniya studencheskoy molodezhi [Military-historical reconstruction as socio-cultural phenomenon and a means of patriotic education of student youth]. Vestnik assotsiatsii vuzov turizma i servisa, 2017, vol. 11, no 4, 104-114 pp.

19. Lokhvytska L.V. Psikhologo-pedagogicheskaya tekhnologiya nravstvennogo vospitaniya doshkol"nikov: innovatsionnyy vzglyad [Psycho-pedagogical technology of moral education of preschoolers: an innovative opinion]. GISAP: Psychological Sciences, 2016, vol. 9, 12-15 pp.

20. Vengerova N.N. Semanticheskiy analiz opredeleniy ponyatiya «pedagogicheskaya tekhnologiya» [Semantic analysis of definitions of the educational technology concept]. Obshchestvo: sotsiologiya, psikhologiya, pedagogika, 2017, vol. 1, 103-106 pp. http://dom-hors.ru/vipusk-1-2017-obshchestvo-sociologiya-psihologiya-pedagogika/ (accessed: February 19, 2019).

21. Sapanzha O.S. Muzeynoe obrazovanie i muzeynaya pedagogika v rossiyskoy akademicheskoy traditsii i praktike muzeynogo dela: granitsy ispol'zovaniya ponyatiy i ikh soderzhanie [Museum education and Museum pedagogy in the Russian academic tradition and practice of Museum business: the boundaries of the concepts use and their content]. Obshchestvo: sotsiologiya, psikhologiya, pedagogika, 2017, vol. 1, 91-95 pp. http://dom-hors.ru/vipusk-1-2017-obshchestvo-sociologiya-psihologiyapedagogika/ (accessed: February 19, 2019).

22. Golovko O.N., Barskaya O.V., Selezneva N.Ye. Moral Education in Foreign Language Training of Future Naval Officers. The European Proceedings of Social \& Behavioural Sciences EpSBS,2018, vol. LI, pp. 1952-1957. https://www.futureacademy.org.uk/ files/images/upload/18thPCSF2018F207.pdf (accessed February 19, 2019).

23. Kagileva A.O. «Politkorrektnost"»: aspekty interpretatsii ["Political correctness": Interpretation aspects]. Vestnik Volgogradskogo gosudarstvennogo universiteta, 2017, vol. 16, no 1, 136-143 pp.

24. Mambetova I.Zh. The functional role of the national and cultural factors in teaching (learning) a foreign language. Higher School Pedagigy, 2016, vol. 2, no. 5, pp. 38-41.

25. Starchikova I.Yu., Moshchenok G.B., Shakurova E.S. Sociological study of the influence of studying foreign languages on the formation of the world outlook and spiritual values of student youth.International Research Journal, 2017, vol. 11, no. 65, pp. $147-151$.

26. Mukhametzyanova F.G., Venidiktova Ye.A., Litvina L.M. Kontsepty dukhovnonravstvennogo vospitaniya studentov voennogo vuza [Concepts of spiritual and moral education of military higher education institution cadets]. Nauchno-metodicheskiy elektronnyy zhurnal «Kontsept», 2018, vol. 12, 1063-1071 pp. https://cyberleninka.ru/article/n/kontsepty-duhovno-nravstvennogo-vospitaniyastudentov-voennogo-vuza (accessed: February 21, 2019).

27. Karpova S.P. (Eds). Admiral M.P. Lazarev. Rol' lichnosti v istorii Rossii [Admiral M.P. Lazarev. The role of personality in Russian history]. Sbornik materialov nauchno-istoricheskoy konferentsii Voenno-nauchnogo obshchestva Chernomorskogo Flota Rossiyskoy Federatsii 6 noyabrya 2013 goda [Materials of the scientific-historical conference of the Military-scientific society of the Black Sea Fleet of the Russian Federation, November 6, 2013]. Sevastopol, Miste, 2013. 182 p.

28. Nikul'chenkov K.I. (Eds). M.P. Lazarev. Dokumenty [M.P. Lazarev. Documentation]. Moscow, Voenizdat, 1961. 580 p. 
29. Novikov N.V., Sofgenov P.G. (Eds). Vitse-admiral Kornilov [Vice-Admiral Kornilov]. Moscow, Voenizdat, 1947. 340 p.

30. Samarova A.A. (Eds). P.S. Nakhimov. Dokumenty [P.S. Nahimov. Documentation]. Moscow, Voenizdat, 1954. 832 p.

Original article submitted 15.01.2019

Revision submitted 21.02.2019

УДК 37.013

\title{
СОЧЕТАНИЕ ИННОВАЦИОННЫХ ТЕХНОЛОГИЙ И ИСТОРИЧЕСКОГО НАСЛЕДИЯ В ДУХОВНО-НРАВСТВЕННОМ ВОСПИТАНИИ КУРСАНТОВ
}

\author{
O.В. Барская ${ }^{\prime}$ \\ ${ }^{1}$ Черноморское высшее военно-морское ордена Красной Звезды училище \\ имени П.С. Нахимова Министерства обороны Российской Федерации \\ 299028, г. Севастополь, ул. Дыбенко П., 1А \\ ${ }^{1}$ E-mail: olyabarska@yahoo.com
}

\begin{abstract}
АННОТАЦИЯ
Статья направлена на разработку рекомендаџий по использованию инновационных форм духовно-нравственного воспитания курсантов для творческого соединения исторического содержания и современных технологий в воспитательном прочессе военных учебных заведений. С этой целью выявлены задачи, новизна, методологическая база и методь исследования. Актуальность рассматриваемого вопроса доказана на основе опроса, проведенного среди курсантов военно-морского флота; проанализирована степень изученности проблемь в современной отечественной и зарубежной науке. На основе недавних научных исследований дань дефиниции понятиям духовность, духовно-нравственное воспитание и инновационные педагогические технологии, определень функции использования информационно-коммуникационных технологий в прочессе обучения. Наиболее существенная часть статьи посвящена методическим рекомендациям по применению технологий «виртуальная экскурсия» $u$ «конкурспроект» в прочессе духовно-нравственного воспитания курсантов военноморского флота. Был разработан проект, предполагающий сочетание использования курсантами информачионных технологий и архивных источников, а также печатных материалов, содержащих краеведческие факты, также были предложены темы для реализации подобных проектов в будущем.
\end{abstract}

Ключевые слова: духовно-нравственное воспитание, инновационные педагогические технологии, военные учебные заведения, виртуальная экскурсия, конкурспроект.

\section{БИБЛИОГРАФИЧЕСКИЙ СПИСОК}

1. Гребенкин А.Н. Военно-культурные традиции подготовки русского офицерского корпуса (2-я половина XVII - начало XX в.): дисс. ... докт. ист. наук: 07.00.02 /

${ }^{1}$ Барская Ольга Владимировна, старший преподаватель кафедры «Иностранные языки». 
Гребенкин Алексей Николаевич; [Место защиты: ФГБОУ ВО Брянский государственный университет имени академика И.Г. Петровского], 2017. - 578 с.

2. Kerimbayeva B.T., Serickbayeva N.M. The formation of moral - spiritual qualities of future teachers in higher pedagogical education. A Young Scientist, 2017, vol. 7, no. 141, pp. 37-39. https://moluch.ru/archive/141/39701 (accessed: February 20, 2019).

3. Miralieva D.T. The impact of mass culture on the formation and development of spiritual and moral image of today's youth. East European Science Journal, 2017, no. 1, pp. 41-45. https://eesa-journal.com/en/2017/02/27/the-impact-of-mass-culture-on-theformation-and-development-of-spiritual-and-moral-image-of-todays-youth/ (accessed: February 20, 2019).

4. Дударенко Е.П. Педагогический мониторинг духовно-нравственного воспитания старшеклассников посредством внеурочной экскурсионной деятельности [Текст] / Е.П. Дударенко // Педагогика. Вопросы теории и практики. - 2018. - № 3(11). - С. 13-18.

5. Дудина Г.О. Музейная педагогика как средство обучения русскому языку как иностранному (на примере моделирования виртуальной экскурсии по музеям Санкт-Петербурга) [Электронный ресурс] / Г.О. Дудина // Современные проблемы науки и образования. - 2017. - № 6; URL: http://scienceeducation.ru/ru/article/view?id=27246 (дата обращения: 19.02.2019).

6. Устюжанина Н.В. Виртуальная экскурсия как инновационная форма обучения [Электронный ресурс] / Н.В. Устюжанина // Наука и перспективы. - 2017. - № 2. - C. 62-66; URL: https://cyberleninka.ru/article/n/virtualnaya-ekskursiya-kakinnovatsionnaya-forma-obucheniya (дата обращения: 19.02.2019).

7. Delvig N.A., Seleznyova N.Ye., Barskaya O.V. Virtual Museum as the Means of Future Naval Officers' Patriotic Upbringing. TSPU Bulletin, 2018, vol. 8, no. 197, pp. 115-120. https://vestnik.tspu.edu.ru/files/vestnik/PDF/articles/delvig_n._a._115_120_ 8_197_2018.pdf (accessed February 20, 2019).

8. Rose J. Commemorative museum pedagogy. In Trofanenko B. \& Segall A. (Eds). Beyond Pedagogy. Reconsidering the Public Purpose of Museums. Rotterdam: Sense Publishers, 2014. 184 p., pp. 115-133.

9. Milovanov K.Yu., Nikitina E.Ye., Sokolova N.L., Sergeyeva M.G. The creative potential of museum pedagogy within the modern society. Revista ESPACIOS, 2017, vol. 38, no. 40, pp. 27-38. http://www.revistaespacios.com /a17v38n40/17384027.html (accessed: February 21, 2019).

10. Belenchuk L.N., Zanaev S.Z., Kondratieva G.V., Milovanov K.Yu., Nikitina E.E., Polovetsky S.D. Historical role of museums and libraries in information support of educational environment. The European Proceedings of Social \& Behavioural Sciences EpSBS, 2018, vol. XLVI, pp. 445-451. https://dx.doi.org/10.15405/ epsbs.2018.09.02.52 EEIA-2018 (accessed: February 20, 2019).

11. Yu Y.M. Comparative study of the military academy moral education model. International Journal of Ethics Education, 2016, no. 1, pp. 25-42.

12. Kudinov S.I., Kudinov S.S., Kudinova I.B., Belousova S.S. The axiological orientation of students' personalities. Psychology in Russia: State of the Art, 2018, vol. 11, no. 1, pp. 95-105.

13. Poda V.N. Theoretical principles of spiritual and moral education defined by V. Zenkovskyi. A Young Scientist, 2016, vol. 3, no. 107, pp. 897-900. https://moluch.ru/archive/107/25620/ (accessed: February 20, 2019). 
14. Hong-Mei Li, Dan Han. Innovation research of moral education based on excellence engineer training program. International Journal of Cognitive Research in Science, Engineering and Education, 2013, vol. 1, no. 2, pp. 106-113.

15. Ferdig R., Coutts J., DiPietro J., Lok B., Davis N. Innovative technologies for multicultural education needs. Multicultural Education \& Technology Journal, 2007, vol. 1, no. 1, pp. 47-63. https://www.learntechlib.org/p/101397/ (accessed: February 18, 2019).

16. Редькина Л.И. Использование информационно-коммуникационных технологий в процессе духовно-нравственного воспитания в образовательных учреждениях военного профиля [Текст] / Л.И. Редькина // Вестник Самарского государственного технического университета. Сер. Психолого-педагогические науки. - 2017. - № 4(36). - C. 121-130.

17. Lapasov N.Sh. The role of innovative technologies in education. A Young Scientist, 2017, no. 15, pp. 598-600. https://moluch.ru/archive/149/42206/ (accessed: February 18, 2019).

18. Максимов С.Н., Степина Е.Г. Военно-историческая реконструкция как социокультурный феномен и средство патриотического воспитания студенческой молодежи [Текст] / С.Н. Максимов, Е.Г. Степина // Вестник ассоциации вузов туризма и сервиса. - 2017. - Т. 11. - № 4. - С. 104-114.

19. Лохвицкая Л.В. Психолого-педагогическая технология нравственного воспитания дошкольников: инновационный взгляд [Текст] / Л.В. Лохвицкая // GISAP: Psychological Sciences. - 2016. - № 9. - C. 12-15; URL: http://scienceeducation.ru/ru/article/view?id=27246 (дата обращения: 19.02.2019).

20. Венгерова Н.Н. Семантический анализ определений понятия «педагогическая технология» [Электронный ресурс] / Н.Н. Венгерова // Общество: социология, психология, педагогика. - 2017. - № 1. - C. 103-106; URL: http://domhors.ru/vipusk-1-2017-obshchestvo-sociologiya-psihologiya-pedagogika/ (дата обращения: 19.02.2019).

21. Сапанжа O.C. Музейное образование и музейная педагогика в российской академической традиции и практике музейного дела: границы использования понятий и их содержание [Электронный ресурс] / О.С. Сапанжа // Общество: социология, психология, педагогика. - 2017. - № 1. - C. 91-95; URL: http://domhors.ru/vipusk-1-2017-obshchestvo-sociologiya-psihologiya-pedagogika/ (дата обращения: 19.02.2019).

22. Golovko O.N., Barskaya O.V., Selezneva N.Ye. Moral Education in Foreign Language Training of Future Naval Officers. The European Proceedings of Social \& Behavioural Sciences EpSBS, 2018, vol. LI, pp. 1952-1957. https://www.futureacademy.org.uk/files/images/upload/18thPCSF2018F207.pdf (accessed February 19, 2019).

23. Кагилева А.О. «Политкорректность»: аспекты интерпретации [Текст] / А.О. Кагилева // Вестник Волгоградского государственного университета. - 2017. - № 16(1). - C. 136-143.

24. Mambetova I.Zh. The functional role of the national and cultural factors in teaching (learning) a foreign language. Higher School Pedagigy, 2016, vol. 2, no. 5, pp. 38-41.

25. Starchikova I.Yu., Moshchenok G.B., Shakurova E.S. Sociological study of the influence of studying foreign languages on the formation of the world outlook and spiritual values of student youth. International Research Journal, 2017, vol. 11, no. 65, pp. $147-151$.

26. Мухаметзянова Ф.Г., Венидиктова Е.А., Литвина Л.М. Концепты духовнонравственного воспитания студентов военного вуза [Электронный ресурс] / Ф.Г. 
Мухаметзянова, Е.А. Венидиктова, Л.М. Литвина // Научно-методический электронный журнал «Концепт». - 2018. - № 12. - C. 1063-1071; URL: https://cyberleninka.ru/article/n/kontsepty-duhovno-nravstvennogo-vospitaniyastudentov-voennogo-vuza / (дата обращения: 21.02.2019).

27. Карпова С.П. Роль адмирала М.П. Лазарева в становлении и развитии культурных учреждений Черноморского флота [Текст] / С.П. Карпова // Адмирал М.П. Лазарев. Роль личности в истории России: сборник материалов научноисторической конференции (Севастополь, 6 ноября 2013 г.) / Севастопольская морская б-ка им. адм. М. П. Лазарева, Военно-научное о-во Черноморского флота Российской Федерации; [сост. Карпова С. П.]. - Севастополь: Мистэ, 2013. C. 32-38.

28. Лазарев М.П. Документы [Текст]: в 3 тт. Т. 3 / сост. К.И. Никульченков. - М.: Воениздат, 1961. $-580 \mathrm{c}$.

29. Вице-адмирал Корнилов [Текст]: документы / под ред. Н.В. Новикова и П.Г. Софгенова. - М.: Воениздат, 1947. - 340 с.

30. Нахимов П.С. Документы [Текст] / под ред. А.А. Самарова. - М.: Воениздат, 1954. $-832 \mathrm{c}$.

Поступила в редакцию 15.01.2019

В окончательном варианте 21.02.2019 